\title{
World production and possible recovery of cobalt from the Kupferschiefer stratiform copper ore
}

\author{
Paulina M. Pazik ${ }^{1,2, a}$, Tomasz Chmielewski ${ }^{2}$, Hylke J. Glass ${ }^{1}$, and Przemyslaw B. Kowalczuk ${ }^{2}$ \\ ${ }^{1}$ Camborne School of Mines, University of Exeter, Tremough Campus, Penryn, Cornwall, TR10 9EZ, UK \\ ${ }^{2}$ Wroclaw University of Science and Technology, Faculty of Geoengineering, Mining and Geology, Wybrzeze \\ Wyspianskiego 27, 50-370 Wroclaw, Poland
}

\begin{abstract}
Cobalt is recognized as a strategic metal and also E-tech element, which is crucial for worlds development. An increasing demand for cobalt forces for searching of new resources that could be explored in European countries. There are many examples of cobalt recoveries, mostly from laterite and sulphide deposits. However, the accurate choice of the technology depends on many factors. The Kupferschiefer stratiform copper ore located in Poland is the biggest deposit of cobalt in Europe. Although KGHM Polska Miedz S.A. recovers many precious metals from this ore, cobalt is not recovered yet. This metal occurs as an accompanying element, mostly in the form of cobaltite (CaAsS), with the average content of $50-80 \mathrm{~g} / \mathrm{Mg}$. In this paper a possible recovery of cobalt from the Kupferschiefer ore, with the use of hydrometallurgical methods, was investigated.
\end{abstract}

\section{Introduction}

In 2014, the European Commission published a report on critical raw materials for the European Union, defining cobalt as a strategic metal. It is due to rising consumption of cobalt and its very low production in European countries. Cobalt is also classified, by the National Environmental Research Council (NERC), as an E-tech element what means that this element is essential for a technological development [1].

Cobalt is a transition metal appearing in the periodic table between iron and nickel. It a silverywhite, shiny, ductile and malleable metal with density of $8.9 \mathrm{~g} / \mathrm{cm}^{3}$ [2]. Cobalt has melting and boiling points at 1495 and $3100{ }^{\circ} \mathrm{C}$, respectively [1]. Cobalt exhibits ferromagnetic properties and can be magnetized to produce permanent magnets since it has the Curie point at $1121{ }^{\circ} \mathrm{C}$, which is higher than any other metal. As a result cobalt exhibits its magnetic properties even at high temperatures [3, 4]. Due to its heat resistance, strength and magnetic properties, cobalt has wide variety of applications. The most common uses are magnets, battery and alloys [5]. In comparison to either nickel or iron alloys the cobalt ones exhibit superior thermal weariness resistance and weldability [4]. Cobalt chrome alloys have the best combination of properties like good strength, corrosion resistance and good tolerance by the human body [6].

\footnotetext{
${ }^{a}$ Corresponding author: paulina.pazik@pwr.edu.pl
} 
Almost all of cobalt that is used in EU comes from resources outside Europe. It was estimated that in 2012 an about 95\% of cobalt was imported came from Russia and 3\% from the United States [1]. The largest World resources of cobalt are located in the Central African Copper Belt in the Democratic Republic of Congo and Zambia, where the resources are estimated to be around 15 million tonnes. An additional one billion tonne may exist in manganese nodules and crusts on the ocean floor [1]. These resources are characterized as not yet economically exploitable, however there are many studies which qualify them as a strategic resource with huge future potential. Almost half of world cobalt production comes from Democratic Republic of the Congo. Figure 1 shows world cobalt mining in 2015. In Europe there are known only some small cobalt resources like the Kupferschiefer copper ore extracted by KGHM Polska Miedz S.A. [1].

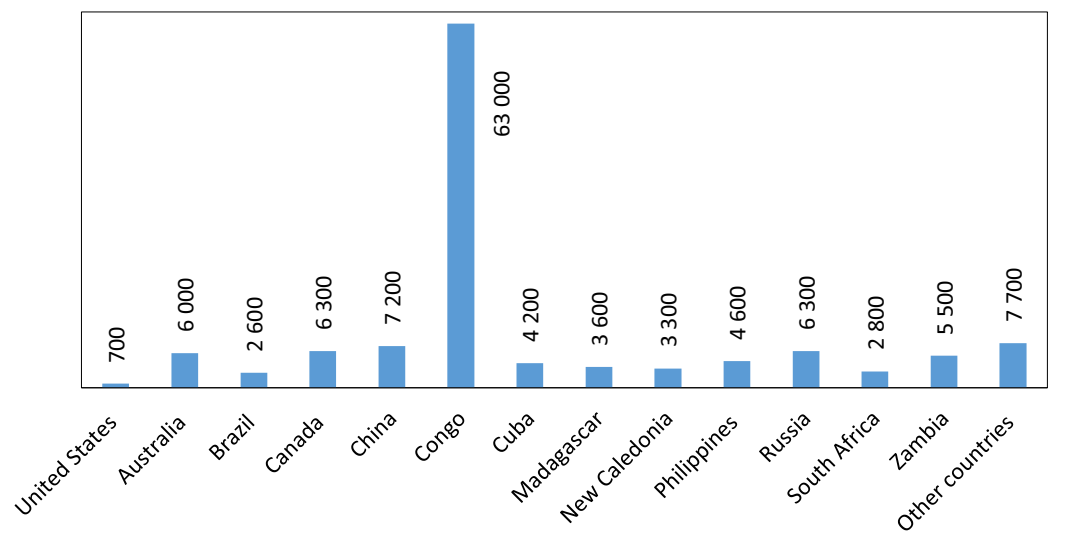

Figure 1. World cobalt mining in 2015, based on [5].

Cobalt is the $33^{\text {th }}$ element in terms of spreading in the earth curst. In nature, cobalt is a dispersed element and its average content in the continental crust is $20 \mathrm{ppm}$ [3]. Cobalt is commonly found in sulphide minerals, associated with copper, nickel and iron. The most common minerals of cobalt are cobaltite (CoAsS), safflorite $\left(\mathrm{CoAs}_{2}\right)$, glaucodot $((\mathrm{Co}, \mathrm{Fe}) \mathrm{AsS})$ and skutterudite $\left(\mathrm{CoAs}_{3}\right)$. Typically, cobalt does not form independent deposits, but it appears as an important component of different types of ores such as copper, silver, bismuth and uranium [4].

Most of metallic cobalt is obtained as a by-product of nickel and copper extraction. Production of cobalt may require combination of chemical, thermal and electrolytic methods. The right technology of cobalt production depends on its concentration, type of ore, other metals production and final form of cobalt products [7]. In this paper possible recovery of cobalt from the Kupferschiefer ore, with the use of hydrometallurgical methods was investigated.

\section{Cobalt extraction and production}

Overall world production of cobalt can be divided in two groups. Approximately half of this output is produced as a by-product of nickel extraction, where the other half is produced from copper mines [8]. Cobalt production depends on the ore type wherein its occurred.

\subsection{Laterite ores}

In this type of ore, cobalt mostly occurs as a goethite $(\mathrm{Fe}, \mathrm{Ni}, \mathrm{Co}) \mathrm{OOH}$. Most of laterite ores are smelted to produce ferronickel, however cobalt cannot be removed during this process. On the other 
hand cobalt can be recovered from the limonite layer of laterite ores by a leaching process [8]. The most common way of cobalt recovery is high-pressure acid leaching in sulfuric acid (HPAL). After leaching cobalt can be recovered with the use of sulphide precipitation, re-dissolution and solvent extraction. Then, it can be recovered by either electrowinning or hydrogen reduction [8].

\subsection{Sulphide ores}

Flotation is the most efficient method for recovery of cobalt from sulphide ores. Flotation concentrates are further either directly processed by smelting and converting or leached [8]. Leaching can be carried out in either hydrochloric acid, ammonia solutions or sulfuric acid [8]. After that cobalt can be recovered by either electrowinning or hydrogen reduction.

A large source of cobalt comes from copper-cobalt ore types like the Central African Copper Belt in the Democratic Republic of Congo and Zambia. The influence of rain, air and vegetative acid make some of this deposits weathered, which can be easily dissolved in sulfuric acid. According to Fisher [7] in some cases flotation is inefficient, therefore a large amount of this metal is lost in flotation tailings from which cobalt can be recovered. The example of such process is the Kolwezi Tailings Project, in which the tailings have a great potential to produce large amount of cobalt with very low cost. The processing would require leaching of using sulfuric acid and after that solvent extraction and electrowinning would be applied to produce metallic cobalt [9].

The problem in pyrometallurgical processing of cobalt is that this metal follows iron during smelting, therefore some of the copper smelter operations generate slags with high cobalt content [7, 17]. These slags could be a great potential of cobalt resource.

\section{Cobalt at KGHM Polska Miedz S.A.}

\subsection{Mineralogy}

In 2007 Bachowski et al. [10] analysed the prospective of extension the resources of KGHM Polska Miedz S.A. It was established that in the context of high prices of some metals, cobalt, molybdenum and platinum group metals would add a great value to this company.

The Kupferschiefer copper ore mined by KGHM Polska Miedz S.A can be divided into three groups. The first one consists of such elements as $\mathrm{Cu}, \mathrm{S}, \mathrm{Pb}$ and $\mathrm{Fe}$ with contents of each above $0.1 \%$. The second group includes such elements as $\mathrm{Zn}, \mathrm{F}, \mathrm{As}, \mathrm{Ni}, \mathrm{Co}, \mathrm{V}, \mathrm{Ag}$, Mo, U which average content oscillates in the range of $10-1000 \mathrm{~g} / \mathrm{Mg}$. The third group consists of $\mathrm{Sb}, \mathrm{Bi}, \mathrm{Th}, \mathrm{Sn}$, $\mathrm{Cd}, \mathrm{Se}, \mathrm{Hg}, \mathrm{Ge}, \mathrm{Re}, \mathrm{Au}, \mathrm{Pd} \mathrm{i} \mathrm{Pt}$ and the average content of each element is less than $10 \mathrm{~g} / \mathrm{Mg}$ [11]. According to Pieczonka [12] the most important cobalt forms of occurrence are minerals from cobaltite (CoAsS)-gersdorffite (NiAsS) series, but this element also occurs as isomorphic impurities in other minerals. Additionally, it was found that cobalt also concentrates in the organic matter especially in copper-bearing shale $[12,14]$.

Cobaltite (CaAsS), as the main cobalt-bearing mineral occurring in the ore mined by KGHM Polska Miedz S.A., appears in all types of lithological fractions. The largest concentration of this mineral was found in the sandstone and shale fractions [11]. The cobalt concentration in the vertical profile of copper ore is shown in Fig. 2. Cobaltite mostly creates small xenomorphic inclusions (10-20 $\mu \mathrm{m})$ in the copper-bearing minerals such as chalcocite, bornite and digenite [11, 12]. Larger concentration of cobalt is observed in the epigenetic veins of ore. Grotowski and Henc [14] provided information on behaviour of cobalt in industrial enrichment circuits and established that cobalt mostly occurred as independent mineral with fine grade.

Due to small size of cobaltite crystals it is very difficult to identify this mineral. Cobalt belongs to the group of common accompanying elements, where its average content in the Kupferschiefer deposit 
is $50-80 \mathrm{~g} / \mathrm{Mg}$, particularly $140 \mathrm{~g} / \mathrm{Mg}$ in the Lubin ore. On this basis, cobalt can be classified as the secondary group of elements, with the local maximum level of $1.7 \%$ [11].

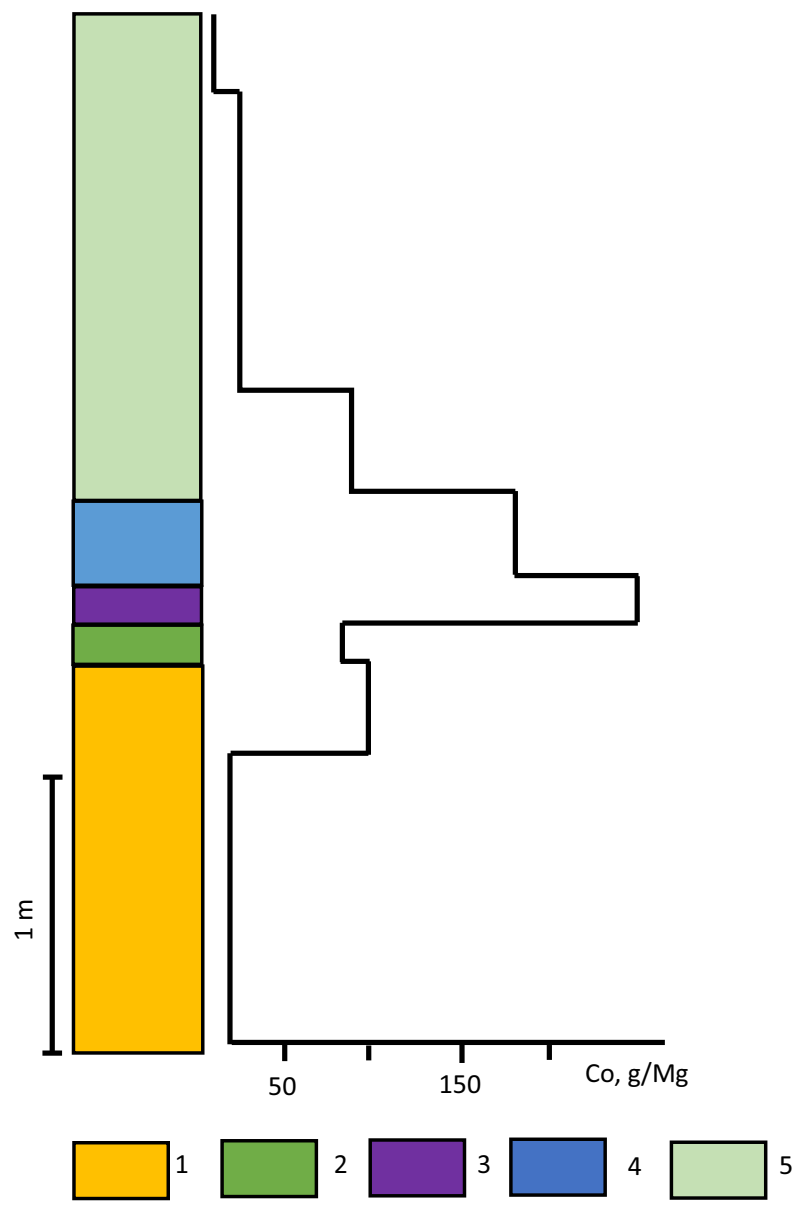

Figure 2. Cobalt concentration in vertical profile of the Kupferschiefer ore, where 1-sandstone, 2-dolomitic sandstone , 3-clay-organic shale, 4-dolomitic shale , 5-dolomite, based on [11, 13].

\subsection{Mineral processing and metallurgy}

The complex mineralogical structure and unique chemical composition of ore mined from sedimentary deposits are reasons of copper, silver, cobalt, molybdenum, nickel and other minerals loses in industrial processing [14]. On the other hand, copper-bearing shale, which contains the highest content of cobalt and high content of organic carbon causes many metallurgical problems at KGHM Polska Miedz S.A. It was found that the content of copper in the excavated ore decreased, however the content of cobalt increased [14]. Kubacz and Skorupska [15] reported that the content of shale fraction in the Lubin deposit exceeded $25 \%$ and it was expected to increase in next years. This situation creates additional technical as well as ecological issues, especially in the smelting process. The increased content of carbonate and organic coal as well as metals disseminated in the ore, especially in the black shale fraction, makes this material difficult to float, but first of all it causes remarkable metals losses [14]. According to Chmielewski [16] the application of modern hydrometallurgy techniques should be considered as a complimentary process for processing, 
particularly for the shale fraction. It would be also beneficial for the cobalt recovery, since it can be recovered by leaching.

\subsubsection{Cobalt recovery from converter slag}

In the smelting process, metals accumulating as by-products of pyrometallurgical processes are mainly $\mathrm{Pb}, \mathrm{Zn}, \mathrm{Re}, \mathrm{As}, \mathrm{Se}, \mathrm{Co}, \mathrm{Hg}, \mathrm{Sb}, \mathrm{Ge}$ and In [17]. These metals accumulate in the form of either dusts or slag as a residue from a dedusting process of gases produced during metallurgical processes. The exception is cobalt, which concentrates in the converter slag (1-2\%) [17]. Some technologies of recovery of cobalt from these slags were proposed. It was found that separation of this metal from the metallic phase was relatively easy for either fire or electrolytic refining. However, separation from the silicate phase required much higher costs. In order to separate cobalt, the slag could be reduced at a high temperature in an electric furnace to the metal alloy, and then cobalt could be easily separated [17]. The possible way of cobalt recovery is shown in Fig. 3.

Converter
Slag $\Rightarrow \begin{aligned} & \text { Reduction in an } \\ & \text { electric furnace }\end{aligned} \Rightarrow \begin{aligned} & \text { Leaching in } \\ & \text { sulfuric acid }\end{aligned} \Rightarrow \begin{gathered}\text { Iron } \\ \text { removal }\end{gathered} \Rightarrow \begin{gathered}\text { Solution } \\ \text { purification }\end{gathered} \Rightarrow$ Electrolysis $\Rightarrow \begin{gathered}\text { Metallic } \\ \text { cobalt }\end{gathered}$

Figure 3. Unit operations of cobalt recovery from converter slag [17].

The alloy received in an electric furnace contained $5-7 \% \mathrm{Co}, 4-5 \% \mathrm{Cu}$, and $85 \% \mathrm{Fe}$. Pure cobalt can be recovered from the alloy by leaching in sulfuric acid. The pollutants from a leaching solution could be recovered by a multi-stage purification process. The final step of this process was electrolysis of cobalt from the purified solution which allowed to produce metallic cobalt [17].

\subsubsection{Cobalt recovery from flotation concentrates}

Cobalt recovery from the flotation concentrates in the oxygenated leaching process has been extensively examined $[16,18,19]$. The results are presented in Fig. 4-10. These studies showed the influence of different factors on the effectiveness of cobalt leaching. The recovery increased with the increase of temperature of solution (studied temperatures were $50,70,90{ }^{\circ} \mathrm{C}$ ) (Fig. 4). The same trend of process occurred with increasing the concentration of iron(III) ions (Fig. 5) and oxygen flow rate (Fig. 6) [18]. Higher oxygen flow rate was beneficial for regeneration of iron(II) ions to iron(III), which in the studies were used as oxidants. As it was expected, the redox potential of slurry decreased in the initial phase of process (Fig. 7). It was due to the dissolution rate of easy-to-leach copper minerals like bornite and chalcocite. In means that the oxygen flow rate is the crucial factor and it has to be controlled in the first phase of process for improving leaching and reducing the redox potential drop.

The effect of chloride ions addition to the leaching solution on recovery of cobalt was also investigated (Fig. 8). Chloride ions are present in the mine water at KGHM Polska Miedz S.A., where its value varies from 3 to $5 \mathrm{~g} / \mathrm{dm}^{3}$ [18]. Even a small addition of chloride ions cause increased in the leaching recovery of cobalt, which would be beneficial for industrial use of this process.

The most important finding in leaching experiments was that the efficiency of cobalt recovery highly depended on the copper recovery (Fig. 9). A strong relationship between cobalt and copper recoveries by oxidative leaching was found. Cobalt started to leach rapidly after recovery of an about 90-95\% of copper. Therefore, it was concluded that cobalt was finely disseminated in the copperbearing minerals.

Figure 10 shows that the recovery of cobalt depended on the sulfuric acid concentration (Fig. 10). Higher concentration enhanced the recovery of cobalt from 0 to $45 \%$ after $10 \mathrm{hrs}$. This results show that leaching can be a sufficient method for recovery of cobalt from the Kupferschiefer ore. Further studies are needed to improve the process. 


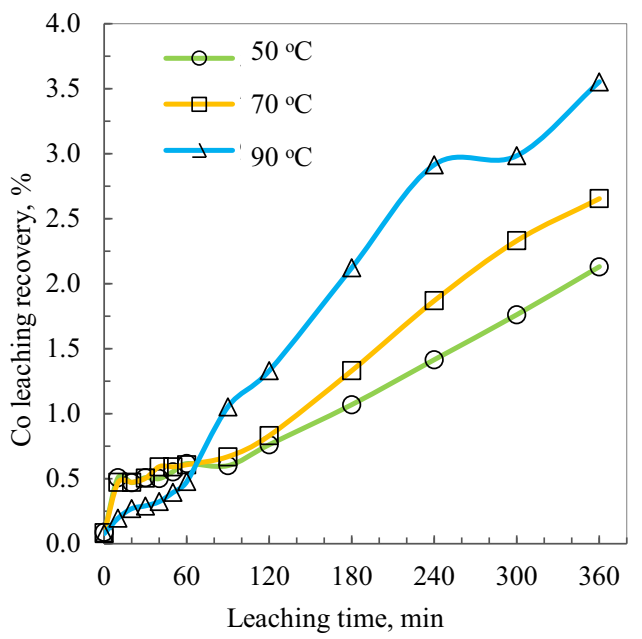

Figure 4. Effect of temperature on Co atmospheric leaching recovery (solid-to-liquid ratio 1:8, initial $\mathrm{H}_{2} \mathrm{SO}_{4}$ concentration $50 \mathrm{~g} / \mathrm{dm}^{3}, \mathrm{O}_{2}$ flow rate $30 \mathrm{dm}^{3} / \mathrm{h}$, based on [18]).

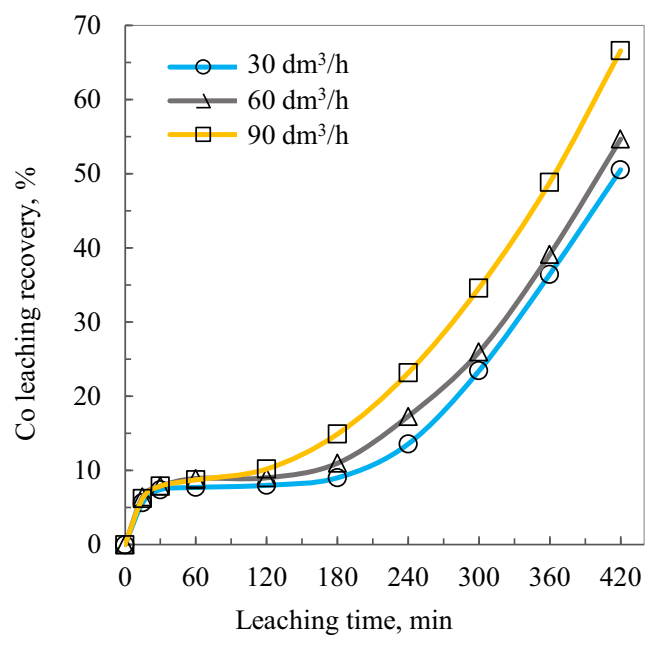

Figure 6. Influence of oxygen flow rate on Co recovery in atmospheric leaching (solid-to-liquid ratio $1: 8, \mathrm{Fe}$ (III) concentration $30 \mathrm{~g} / \mathrm{dm}^{3}$, temperature $90^{\circ} \mathrm{C}$, initial $\mathrm{H}_{2} \mathrm{SO}_{4}$ concentration $50 \mathrm{~g} / \mathrm{dm}^{3}$, based on [18]).

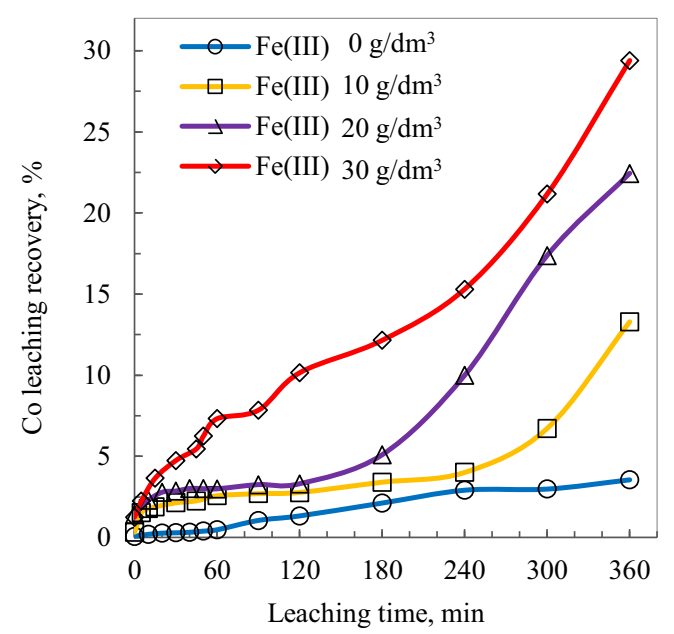

Figure 5. Effect of $\mathrm{Fe}(\mathrm{III})$ ions concentration on Co recovery in atmospheric leaching (solid-to-liquid ratio $1: 8, \mathrm{O}_{2}$ flow rate $30 \mathrm{dm}^{3} / \mathrm{h}, \mathrm{Fe}$ (III) concentration 50 $\mathrm{g} / \mathrm{dm}^{3}$, temperature $90^{\circ} \mathrm{C}$, initial $\mathrm{H}_{2} \mathrm{SO}_{4}$ concentration $50 \mathrm{~g} / \mathrm{dm}^{3}$, based on [18]).

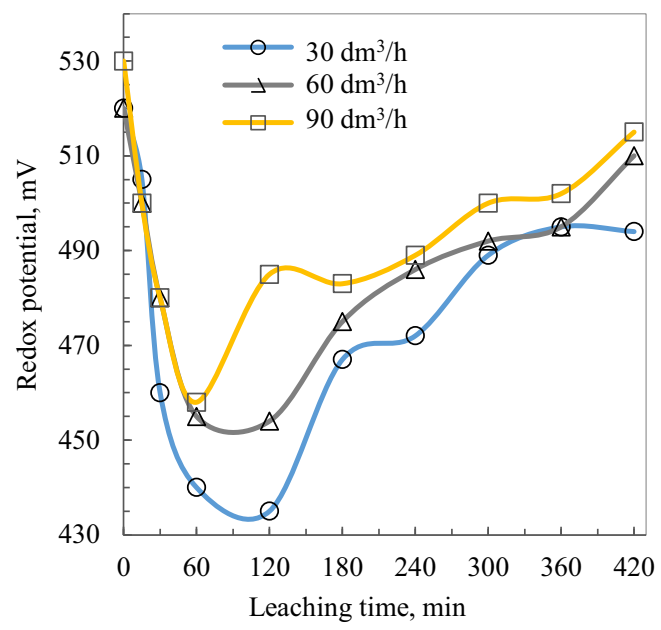

Figure 7. Effect of oxygen flow rate on the redox potential (solid-to-liquid ratio $1: 8, \mathrm{O}_{2}$ flow rate 30 $\mathrm{dm} 3 / \mathrm{h}, \mathrm{Fe}(\mathrm{III})$ concentration $50 \mathrm{~g} / \mathrm{dm}^{3}$, temperature 90 ${ }^{\circ} \mathrm{C}$, initial $\mathrm{H}_{2} \mathrm{SO}_{4}$ concentration $50 \mathrm{~g} / \mathrm{dm}^{3}$, based on [18]). 


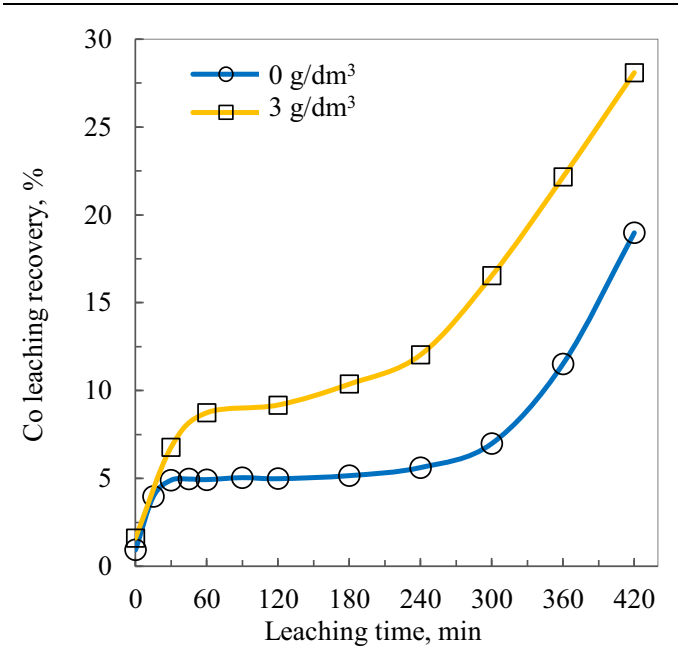

Figure 8. Influence of chloride ions addition on $\mathrm{Co}$ atmospheric leaching (solid-to-liquid ratio 1:6, $\mathrm{O}_{2}$ flow rate $60 \mathrm{dm}^{3} / \mathrm{h}, \mathrm{Fe}(\mathrm{III})$ concentration $30 \mathrm{~g} / \mathrm{dm}^{3}$, temperature $90{ }^{\circ} \mathrm{C}$, initial $\mathrm{H}_{2} \mathrm{SO}_{4}$ concentration 50 $\mathrm{g} / \mathrm{dm}^{3}$, based on [18]).

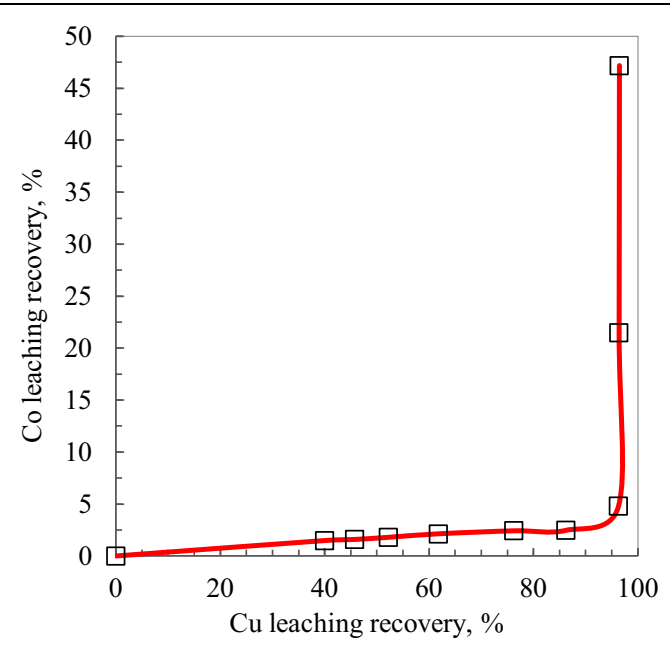

Figure 9. Relationship between $\mathrm{Co}$ and $\mathrm{Cu}$ recoveries in atmospheric leaching (solid-to-liquid ratio 1:6; $\mathrm{Fe}(\mathrm{III})$ concentration $30 \mathrm{~g} / \mathrm{dm}^{3}, \mathrm{O}_{2}$ flow rate $60 \mathrm{dm}^{3} / \mathrm{h}$, temperature $90^{\circ} \mathrm{C}$, initial $\mathrm{H}_{2} \mathrm{SO}_{4}$ concentration 100 $\mathrm{g} / \mathrm{dm}^{3}$, based on [18]).

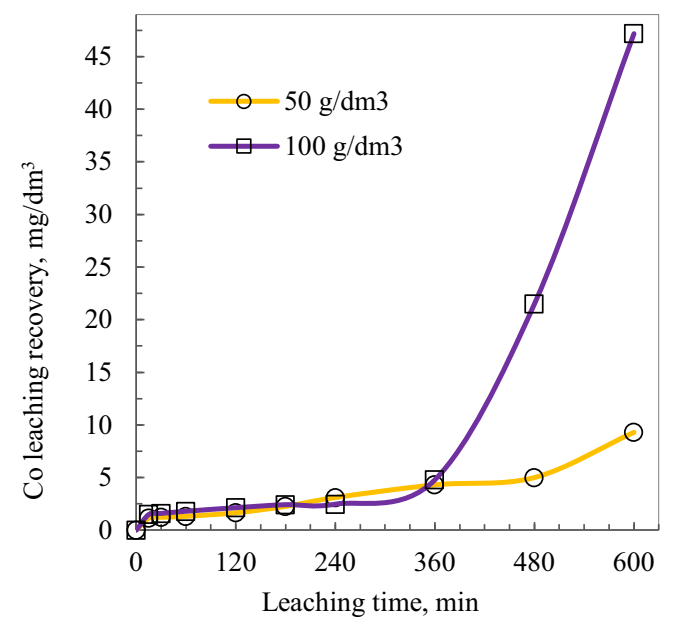

Figure 10. Influence of initial sulphuric acid concentration on Co atmospheric leaching recovery (solid-to-liquid ratio $1: 6, \mathrm{Fe}(\mathrm{III})$, concentration $30 \mathrm{~g} / \mathrm{dm}^{3}$, temperature $90^{\circ} \mathrm{C}, \mathrm{O}_{2}$ flow rate $30 \mathrm{dm} / \mathrm{h}$, based on [18]).

Wodka et al. [19] investigated pressure leaching of black shale middlings in the presence of $\mathrm{H}_{2} \mathrm{SO}_{4}$ solution, at high temperature and high pressure of oxygen. There are many advantages of application of pressure leaching like the high rate of reaction, high recovery of noble metals, high selectivity or elimination of lower gases and dust emission [19]. Pressure leaching was carried out at higher temperatures from 100 to $180{ }^{\circ} \mathrm{C}$. The results showed that cobalt leaching at temperature below $120{ }^{\circ} \mathrm{C}$ did not occur (Fig. 12). Cobalt started to leach at higher temperatures. With increasing temperature above $140{ }^{\circ} \mathrm{C}$ the recovery increased up to $40-50 \mathrm{mg} / \mathrm{dm}^{3}$. Additionally, the influence of initial sulfuric acid concentration and oxygen partial pressure on the cobalt recovery was also investigated. It was shown that no changes in the cobalt recovery at different acid concentrations were observed, while higher pressure provided better results [19]. 


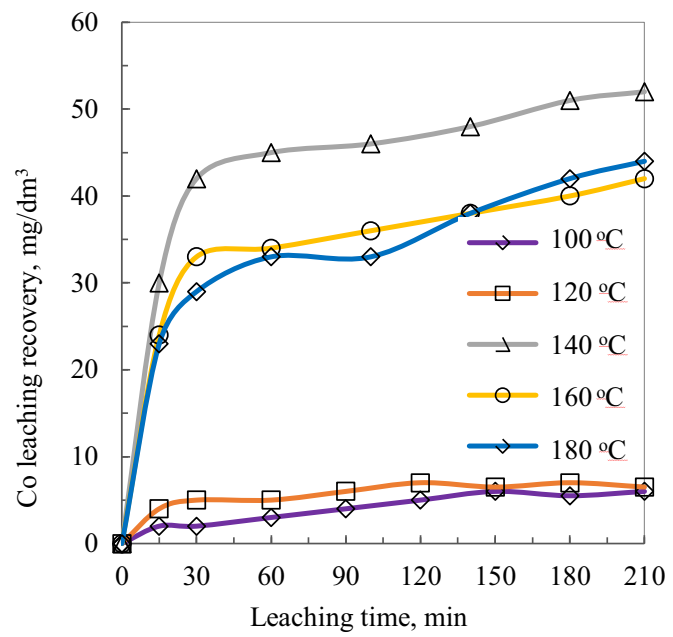

Figure 11. Influence of temperature on pressure leaching of Co (solid-to-liquid ratio 1:10, oxygen partial pressure 0.5 at, initial $\mathrm{H}_{2} \mathrm{SO}_{4}$ concentration 50 $\mathrm{g} / \mathrm{dm}^{3}$, based on [19])

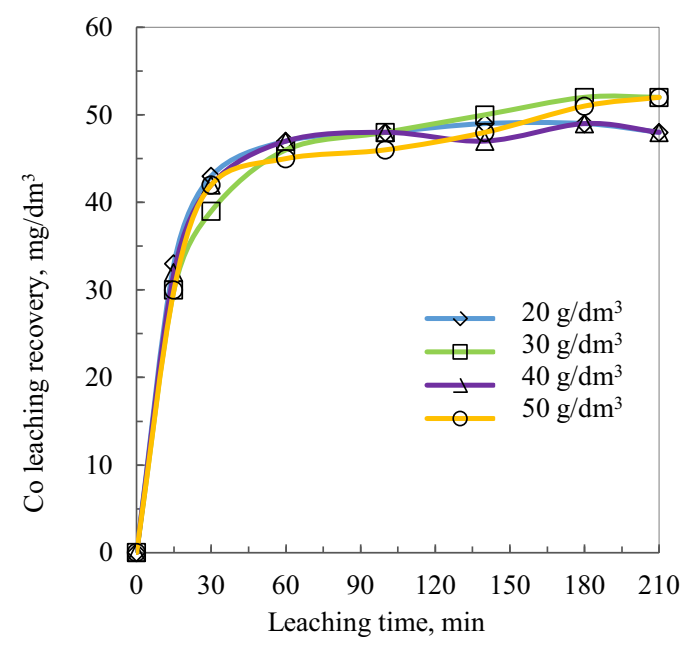

Figure 12. Effect of sulfuric acid concentration on Co pressure leaching (solid-to-liquid ratio 1:10, oxygen partial pressure $0.5 \mathrm{~atm}$, temperature $140{ }^{\circ} \mathrm{C}$, initial $\mathrm{H}_{2} \mathrm{SO}_{4}$ concentration $50 \mathrm{~g} / \mathrm{dm}^{3}$, based on [19]).

Recovery of valuable metals from pregnant leach solutions (PLS) has to be followed by purification and separation, which can be done with the use of solvent extraction. Rotuska and Chmielewski [14] studied the copper(II), cobalt(II), and nickel(II) recovery from PLS after atmospheric leaching of the Lubin shale fraction. Cobalt was recovered by extraction of copper with extractants such as LIX 84, LIX 612 and LIX 984. After that copper free raffinate zinc was extracted with use of di-(2-ethylhexyl)phosphoric acid (D2EHPA). At that point cobalt and nickel were separated from the zinc free raffinate with di-(2,2,4-trimethylpentyl)phosphinic acid (Cyanex 272), where all extractants were dissolved in kerosene [14]. The results showed that cobalt could be sufficiently extracted from PLS. However, the applied extractants were not enough selective, what resulted in transition of other metals to the organic phase. Additionally, it was proved that the recovery of copper, cobalt and nickel was better from the solutions obtained from leaching of shale without use of iron salts. Therefore, there is a need for further studies in this area to find the most optimal conditions of extraction and reextraction processes for the Kupfeschiefer cooper ore.

\section{Conclusions}

Although process of cobalt recovery is very complex, there are many examples that it could be possible and profitable. Considering the world demand for this metal and its many applications, cobalt is classified as a strategic metal. There is a possibility to recover cobalt from the Kupferschiefer ore mined by KGHM Polska Miedz S.A. Due to unique mineralogy of this ore, it is difficult to find an efficient technology for recovery of cobalt. The previous studies showed that it is possible to recover cobalt with the use of leaching technology, both for flotation concentrates as well as converter slag, where currently cobalt is cumulating in metallurgical processes.

\section{Acknowledgement}

This work was partially financed by the Polish Statutory Research Grant 0401/0121/16. 


\section{References}

1. European Comission, Report on Critical Raw Materials for the EU (2014)

2. E. Lewicka, Gospod. Surowcami Min. 23 (2), 5 (2007)

3. G.F. Nordberg, B.A. Fowler, M. Nordberg., Handbook on the Toxicology of Metals, (Elsevier, 2015)

4. C.Y. Cheang, N. Mohamed, Sep. Purif. Technol., 162, 154 (2016)

5. Cobalt Development Institute, Cobalt Facts, http://www.thecdi (2016)

6. S. Hannis, T. Bide, A. Minkd, Raport of BGS (United Kingdom, 2009)

7. K.G. Fisher, in Preccedings of The Southern African Institute of Mining and Metallurgy, $6^{\text {th }}$ Southern African Base Metals Conference (2011)

8. F. Crundwell, M. Moats, V. Ramachandran, T. Robinson, W.G. Davenport, Extractive Metallurgy of Nickel, Cobalt and Platinum Group Metals (Elsevier, 2011)

9. Kolwezi Tailings Project, Raport (SRK Consulting, Democratic Republic of the Congo, 2008)

10. C. Bachowski, J. Kudełko, H. Wirth, Biul. P.I.G., 423, 189 (2007)

11. J. Dabski, Dunaj A., Markiewicz M., Paździora J., Rydzewski A., Siewierski S., KGHM Polska Miedz S.A. Monograph, Edited by: Banaszak A., Banas M. (1996)

12. J. Pieczonka, Prawidłowosci $w$ rozmieszczeniu minerałów kruszczowych $w$ zlożu rud miedzi na monoklinie przedsudeckiej (Wydawnictwo AGH, Krakow, 2011)

13. KGHM Polska Miedz S.A., http://kghm.com/en (2016)

14. A. Grotkowski, T. Henc, in Proceedings of. International Conference Metale towarzyszace $w$ przemysle metali nieżelaznych (Wrocław, 2008)

15. N. Kubacz, B. Skorupska, in Proceedings of VIII International Conference on Non-ferrous Ore Processing (KGHM Cupru, Wroclaw 2007)

16. T. Chmielewski, Physicochem. Probl. Miner. Process, 41, 337 (2007)

17. A. Rapacz, in Proccedings of Konferencja Naukowa, Złoza rud miedzi - geologia, mineralogia, stan badan, perspektywy (Lubin, 1998)

18. K. Gibas, K. Borowski, T. Chmielewski, K. Wejman, Physicochem. Probl. Miner. Process. 51(1), $191(2014)$

19. J. Wodka, T. Chmielewski, B. Ziółkowski, Physicochem. Probl. Miner. Process. 41(1), 349 (2007) 